\title{
The impact of hypoestrogenism and occlusal function on MMP1, MMP8 and MMP13 expression in the odontogenic region in rats
}

\author{
Impacto do hipoestrogenismo e da função oclusal na expressão de MMP1, MMP8 e MMP13 na \\ região odontogênica em ratos
}

El impacto del hipoestrogenismo y la función oclusal en la expresión de MMP1, MMP8 y MMP13

en la región odontogénica en ratas

Received: 04/21/2021 | Reviewed: 04/26/2021 |Accept: 04/29/2021 | Published: 05/14/2021

Isabela Ribeiro Madalena

ORCID: https://orcid.org/0000-0002-4486-1318

Positivo University, Brazil

E-mail: isabelarmadalena@hotmail.com

Cláudia Salete Judachesci

ORCID: https://orcid.org/0000-0002-5580-7958 Positivo University, Brazil

E-mail: claudia_judachesci@ hotmail.com

Erika Calvano Küchler

ORCID: https://orcid.org/0000-0001-5351-2526

Positivo University, Brazil

E-mail: erikacalvano@gmail.com

Paulo Nelson-Filho

ORCID: https://orcid.org/0000-0001-8802-6480

University of São Paulo, Brazil

E-mail: nelson@forp.usp.br

Lucas Alexandre Ramazzoto

ORCID: https://orcid.org/0000-0002-4579-4073

Federal University of São Carlos, Brazil

University of São Paulo, Brazil

E-mail: lucasramazzotto@gmail.com

Flares Baratto-Filho

ORCID: https://orcid.org/0000-0002-5649-7234

University of the Region of Joinville, Brazil

E-mail: fbaratto1@gmail.com

Kesly Mary Ribeiro Andrades

ORCID: https://orcid.org/0000-0002-5718-7211

University of the Region of Joinville, Brazil

E-mail: keslyribeiro@hotmail.com

Sabrina Schulze

ORCID: https://orcid.org/0000-0002-0122-5688

Synlab, Fresing, Germany

E-mail: saschulze2@gmail.com

João César Zielak

ORCID: https://orcid.org/0000-0003-3393-3491

Positivo University, Brazil

E-mail: jzielak2@gmail.com

João Armando Brancher

ORCID: https://orcid.org/0000-0002-8914-702X

Positivo University, Brazil

E-mail: brancher.a@gmail.com

\begin{abstract}
Background: The impact of estrogen deficiency and occlusion in the matrix metalloproteinases (MMPs) expression in dental tissues has not yet been elucidated. Objective: To evaluate the influence of estrogen deficiency and occlusal hypofunction and hyperfunction on the gene expression of MMP1, MMP8 and MMP13 in the odontogenic region of teeth in continuous growth, in the murine model. Material and methods: Rats (Wistar Hannover lineage) were divided into two groups according to the intervention received: Hypoestrogenism Group - ovariectomy surgery and Control Group - fictitious surgery. Occlusal hypofunction and hyperfunction conditions were also established in all animals (each animal presented both conditions). After euthanasia, the hemimandibles were removed to evaluate the gene expression through real time PCR. T-test was used to compare the mean differences between groups $(P<0.05)$. Results:
\end{abstract}


There was no statistically significant difference of the relative gene expression of MMP1, MMP8 and MMP13 between the hypoestrogenism and control groups $(P>0.05)$. A statistically significant difference of the relative MMP13 expression between the occlusal hypofunction and hyperfunction tooth was observed $(P=0.03)$. In the hypoestrogenism group, MMP13 was overexpressed in hypofunction tooth $(P=0.045)$. Conclusion: Occlusal function affects MMP13 expression in the odontogenic region, in murine model.

Keywords: Dental sac; Estrogens; Matrix metalloproteinases; Osteogenesis.

\section{Resumo}

Introdução: O impacto da deficiência de estrógeno e da oclusão na expressão das metaloproteinases da matriz (MMPs) nos tecidos dentários ainda não foi elucidado. Objetivo: Avaliar a influência da deficiência de estrógeno e da hipofunção e hiperfunção oclusal na expressão gênica de MMP1, MMP8 e MMP13 na região odontogênica de dentes em crescimento contínuo, no modelo murino. Material e métodos: Ratas (linhagem Wistar Hannover) foram divididas em dois grupos de acordo com a intervenção recebida: Grupo Hipoestrogenismo - cirurgia de ovariectomia e Grupo Controle - cirurgia fictícia. Condições de hipofunção e hiperfunção oclusal também foram estabelecidas em todos os animais (cada animal apresentava ambas as condições). Após a eutanásia, as hemimandíbulas foram retiradas para avaliação da expressão gênica por meio de PCR em tempo real. O teste $\mathrm{t}$ foi usado para comparar as diferenças médias entre os grupos $(P<0,05)$. Resultados: Não houve diferença estatisticamente significativa da expressão gênica relativa de MMP1, MMP8 e MMP13 entre os grupos de hipoestrogenismo e controle $(P>0,05)$. Foi observada uma diferença estatisticamente significativa da expressão relativa de MMP13 entre a hipofunção oclusal e a hiperfunção dentária $(P=0,03)$. No grupo de hipoestrogenismo, MMP13 foi superexpresso no dente com hipofunção $(P=0,045)$. Conclusão: A função oclusal afeta a expressão de MMP13 na região odontogênica, em modelo murino.

Palavras-chave: Saco dentário; Estrógeno; Metaloproteinases da matriz; Osteogenese.

\section{Resumen}

Antecedentes: El impacto de la deficiencia de estrógeno y oclusión dentaria sobre la expresión de metaloproteinasas de la matriz (MMPs) en los tejidos dentales aún no ha sido suficientemente estudiada. Objetivo: Evaluar la influencia de la deficiencia de estrógeno y función oclusal (hipo- e hiperfunción) sobre la expresión génica de MMP1, MMP8 y MMP13 en la región odontogénica de dientes con erupción continua, usando un modelo murino. Materiales y métodos: Ratas del linaje Wistar-Hannover fueron divididas en dos grupos de acuerdo a la intervención recibida: grupo con hipoestrogenismo - cirugía de ovariectomía, y grupo control - cirugía ficticia. Fueron creadas condiciones de hipo-e hiperfunción oclusal en los animales (cada animal presentó ambas condiciones). Una vez realizada la eutanasia, las hemimandíbulas fueron separadas para evaluar la expresión génica por medio de PCR en tiempo real. Se utilizó la prueba t para comparación entre los grupos $(P=0,05)$. Resultados: No hubo diferencia estadísticamente significativa en la expresión genética relativa de MMP1, MMP8 y MMP13 entre el grupo con hipoestrogenismo y el grupo control $(P>0,05)$. Se observó una diferencia estatísticamente significativa en la expresión de MMP13 entre los grupos con hipoe hiperfunción oclusal $(P=0,03)$. MMP13 fue sobre expresada en los dientes con hipofunción del grupo de animales con hipoestrogenismo $(P=0,045)$. Conclusión: La función oclusal afecta la expresión de MMP13 en la región odontogénica, en modelo murino.

Palabras clave: Saco dental; Estrógenos; Metaloproteinasas de la matriz; Osteogénesis.

\section{Introduction}

Estrogen is a steroidal hormone with lifelong production in the human body. In addition to the well-established relationship in male and female reproduction and in several other systems of the human body, estrogen has also been associated with several conditions, such as obesity, metabolic disorder, cancers, osteoporosis, lupus erythematosus, endometriosis, and uterine fibroids (Patel et al., 2018). The classic pathway by which estrogen performs its function is mediated by its intracellular receptors, the two most studied types are estrogen receptor alpha (ER $\alpha)$ and estrogen receptor beta (ER $\beta)(\operatorname{Paterni}$ et al., 2014). Recent research shows that estrogen receptors are expressed in oral tissues, especially in dental cells with great potential for differentiation, such as dental pulp cells and the odontogenic region of teeth in continuous growth (Alhodhodi et al., 2017; Madalena, 2020; Manokawinchoke et al., 2016).

Increasing evidence also shows the involvement of estrogen in matrix metalloproteinases (MMPs) activity (Jung et al., 2010; Lu et al., 2006). The influence of estrogen and estrogen receptors on the expression of MMPs has already been described in chondrocytes (Lee et al., 2003), osteoblasts (Schiltz et al., 2008), fibroblasts of epithelial tissue (Philips \& Devaney, 2003), stromal endometrial cells (Kokorine et al., 1996), and endothelial cells involved in breast carcinogenesis (Nilsson et al., 2007), 
among others. The increase in the MMPs levels has also been described before under estrogen deficiency condition, also known as hypoestrogenism (Lee et al., 2003).

The family of MMPs is divided into six main groups of proteases (Birkedal-Hansen et al., 1993). In special, the collagenases, composed of interstitial collagenase (MMP1), neutrophilic collagenase (MMP8), and collagenase-3 (MMP13), stimulate cells such as fibroblasts and osteoblasts to cause tissue damage (Souza \& Line, 2001). The expression of MMP1, MMP8, and MMP13 has already been associated with collagen remodeling during periodontal tissue destruction (Al-Majid et al., 2018; Hernandez et al., 2006; Zhang et al., 2011). These MMPs were also involved tooth eruption process (Pizzol-Júnior et al., 2018; Tsubota et al., 2002) and during mechanical force overlapping the periodontal ligament in dysfunctional occlusive conditions (Huang et al., 2008).

Therefore, it is possible to hypothesize that hypoestrogenism, as well as occlusal condition (hypofunction and hyperfunction) may affect the expression of MMP1, MMP8, and MMP13 in the odontogenic region. In occlusive stress condition, represented by occlusal hypofunction or hyperfunction, there is an increase in collagen synthesis, due to the increased remodeling of the extracellular matrix (Kanoza et al., 1980; Omar et al., 2018). Thus, the present study aimed to evaluate the influence of hypoestrogenism and occlusal function on MMP1, MMP8, and MMP13 genes expression, in the odontogenic region, in rats.

\section{Methodology}

\subsection{Ethical Aspects}

This research was performed and reported according to the ARRIVE guidelines (Kilkenny et al., 2010). The Ethical Committee in Animal Experimentation from the School of Dentistry of Ribeirão Preto, University of São Paulo, Brazil, approved this study (\#2018.40.58.3). All efforts were made to minimize animal suffering.

\subsection{Experimental design}

Samples from Wistar Hannover lineage rats were divided from two groups, Hypoestrogenism Group $(\mathrm{n}=10)$ and Control Group ( $\mathrm{n}=10)$ were used in this study (Madalena, 2020). The animals came from the Central Bioterium of the University of São Paulo - Ribeirão Preto Campus and were requested with 21 days of post-uterine life, corresponding to the pre-pubertal period (Ojeda et al., 1976). The mean weight of the animals was 62.04 grams ( $\mathrm{SD}=14.31)$. The animals were stored in collective cages (4 animals per cage), in a controlled temperature environment and a 12-hour light-dark cycle, with free demand for the feed (Labina Purina ${ }^{\circledR} /$ Agribrands do Brasil LTDA, Paulínia, BR) and filtered water ad libitum.

\subsection{Hypoestrogenism - Estrogen deficiency model}

To create estrogen deficiency (decrease the endogenous production of estrogen), a bilateral surgical excision of the ovaries (ovariectomy) was performed in the hypoestrogenism group. While the control group was submitted to fictitious surgery, in which the ovaries were moved and returned to their initial position, as previously described in Omori et al. (2020).

The success of the surgical procedure was confirmed by the animals' survival, gradual increase in body weight during the experimentation period and by the uterine atrophy after euthanasia in the experimental group (Omori et al., 2020). The decrease in endogenous estrogen release, caused by ovariectomy, provides significant differences in the body weight and uterine weight (Chen et al., 2014). Thus, the hypoestrogenism group presented an increase in body weight and a decrease in the uterus weight when compared to the control group $(p<0.05)$.

\subsection{Procedures for simulating the occlusal hypofunction and hyperfunction conditions of teeth with continuous growth}

The occlusal hypofunction condition was simulated adjusting the incisal edge, at the level of the gingival papilla, in the 
lower right incisor (Lee et al., 2002). Consequently, the contra-lateral side presents a hyper occlusal function, and thus the occlusal hyperfunction condition was establishes in the lower left incisor. These are demonstrated in the Figure 1.

Figure 1. Occlusal hypofunction and hyperfunction condition performed on the lower incisors during the pubertal period. The hypofunction condition was performed on the right lower incisor by adjusting the incisal edge at the level of the gingival papillae. The adjustment was performed with a double-sided diamond disk 7011 (KG Sorensen ${ }^{\circledR}$, Cotia, BR) $0.18 \mathrm{~mm}$ thick.

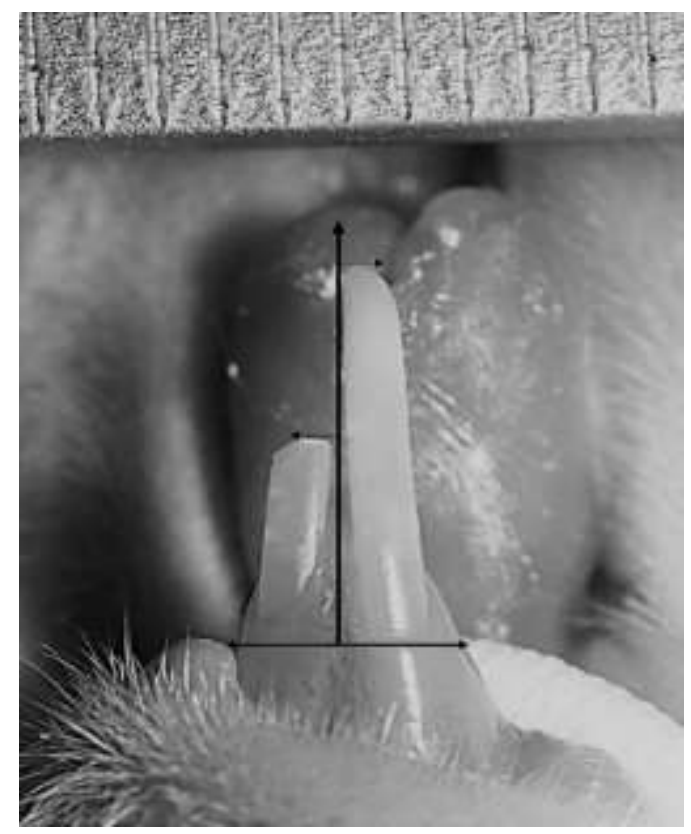

Source: Authors.

Both conditions were reestablished every 48 and 72 hours due to the continuous growth of the incisors of the murine model. The animals were sedated intramuscularly to cut their teeth. After 21 consecutive days, the animals were euthanized.

\subsection{Euthanasia and preparation of specimens}

Euthanasia was carried out following the guidelines of the National Council for the Control of Animal Experimentation - CONCEA. Anesthetic overdose was performed through the combination of ketamine hydrochloride $(300 \mathrm{mg} / \mathrm{Kg}$ of weight) and xylazine hydrochloride (30 $\mathrm{mg} / \mathrm{Kg}$ of weight), which are also available on the Ethics Committee for Animals Use website at www.forp.usp br. Additionally, as suggested by the Ethics Committee for Animals Use to ensure the optimization of procedures, decapitation was also adopted. Therefore, the hemimandibles were removed, dissected, and sectioned to isolate the odontogenic region for gene expression analysis (Figure 2). 
Figure 2. Schematic illustration of the intact hemimandibula and isolated odontogenic region. Note in (A) the intact hemimandible. The black circle delimits the odontogenic region that will be isolated. In (B), the delimitation is noted. The condyle region, coronoid process, mandible branch, and anterior region were removed to avoid increasing the relative expression of MMP1, MMP8, and MMP13 in these regions. In (C), the sectioned odontogenic region is noted.

(A)

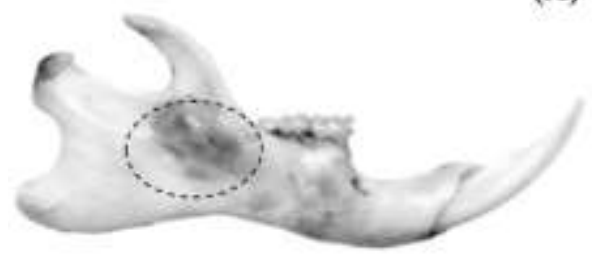

(B)

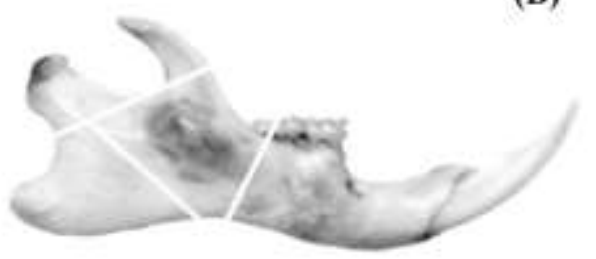

Source: Authors.

\subsection{Analysis of MMP1, MMP8 e MMP13 in odontogenic region - RT-qPCR}

The specimens were kept in RNAlater (Life Technologies Corporation - Carlsbad ${ }^{\circledR}$, Canada, USA) and frozen at $-80^{\circ} \mathrm{C}$ until the day of processing. The mirVana ${ }^{\text {TM }}$ miRNA Isolation kit (Thermo Fischer Scientific, Carlsbad, USA) was used to extract total RNA. Complementary DNA (cDNA) was synthesized by reverse-transcription with a Hight Capacity Kit (Applied Biosystems, Foster City, CA, USA). RT-qPCR was carried out on a StepOnePlus ${ }^{\mathrm{TM}}$ sequence detection system (Applied Biosystems $^{\mathrm{TM}}$, Foster City, CA, USA) using TaqMan ${ }^{\circledR}$ primers and probes (Thermo Fisher Scientific, MA, USA) for MMP1 (Rn01486634-m1), MMP8 (Rn00573646-m1) and MMP13 (Rn01448194-m1). GAPDH (Rn01462661-g1) and ACTB (Rn01412977-g1) were used as endogenous controls. The relative levels of mRNA expression were determined by the $2^{-\Delta \Delta} \mathrm{Cycle}$ Threshold (2- ${ }^{-\Delta \Delta C T}$ ) method (Omori et al., 2020). Both, GAPDH and ACTB, genes were used for sample normalization to calculate the relative quantification. All procedures were performed following the respective manufacturer's instructions and according to established protocols.

\subsection{Statistical analysis}

The data were evaluated using the GraphPad Prism 7.04 software (GraphPad Software ${ }^{\circledR}$, La Jolla, USA), with a significance of 5\%. Normality was tested using the Shapiro-Wilk test. Student's t test was used to compare the means between the hypoestrogenism and control groups. Paired student's t test was used to compare the means between the sides with occlusal hypofunction or hyperfunction.

\section{Results}

The analysis was performed in the survival animals: Hypoestrogenism Group $(n=8)$ and Control Group ( $n=9)$. The difference in MMP1, MMP8 and MMP13 expression in the odontogenic region of the lower incisors of both groups (hypoestrogenism and control), are shown in Figure 3. The mean and standard deviation (SD) of MMP1 relative gene expression level was $1.06(\mathrm{SD}=0.39)$ for the hypoestrogenism group and $0.85(\mathrm{SD}=0.29)$ for the control group. For MMP8, the mean relative gene expression level was $0.78(\mathrm{SD}=0.38)$ for the hypoestrogenism group and $1.03(\mathrm{SD}=0.25)$ for the control group. For MMP13, the mean relative gene expression level was $1.06(\mathrm{SD}=0.38)$ for the hypoestrogenism group and $1.06(\mathrm{SD}=0.36)$ for the control group. There were no statistically significant differences between the groups $(P=0.33, P=0.12$ and $P=0.97$, respectively). 
Figure 3. Relative gene expression of MMP1 (A), MMP8 (B) and MMP13 (C) in the odontogenic region of the hypoestrogenism and control groups. There was no statistically significant difference $(P>0.05)$.

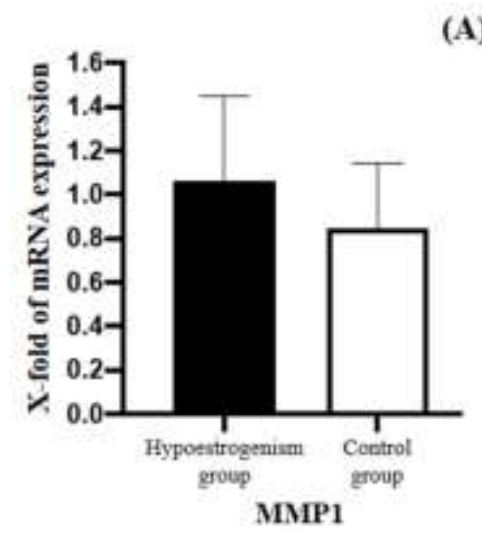

(A)

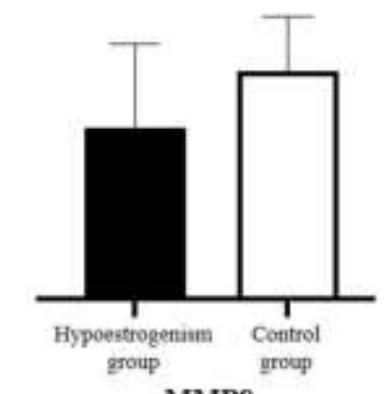

MMP8
(B)

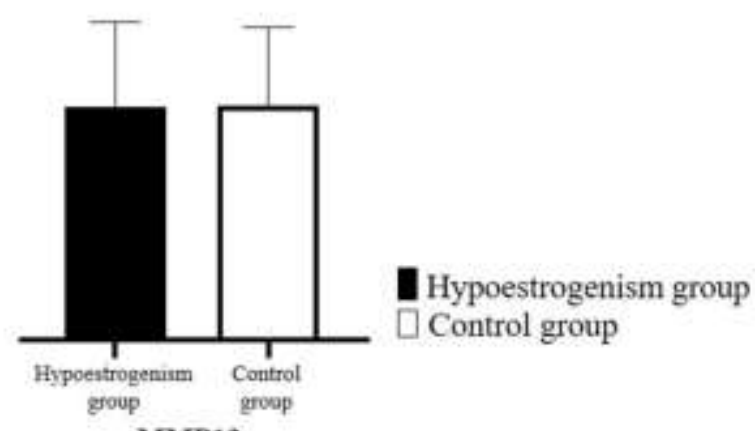

MMP13

Source: Search data.

The difference in MMP1, MMP8 and MMP13 expression in the odontogenic region of the lower incisors of both conditions (occlusal hypofunction and hyperfunction), are shown in Figure 4. MMP1 and MMP8 expression were not statistically significant different between occlusal hypofunction and hyperfunction $(P=0.70$ and $P=0.16$, respectively). The mean distribution of the relative gene expression of MMP13 showed a statistically significant difference between the occlusal hypofunction and hyperfunction teeth $(P=0.03)$. In the hypoestrogenism group, MMP13 was overexpressed in hypofunction teeth $(P=0.045)$.

Figure 4. Relative gene expression of MMP1, MMP8 and MMP13 in the odontogenic region in teeth with occlusal hypofunction and hyperfunction. MMP13 demonstrated a significant difference between hypofunction and hyperfunction conditions $(P=0.03)$.

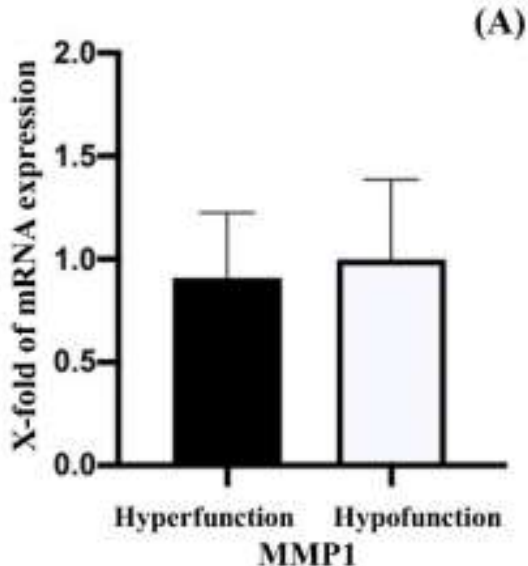

MMP1

(A)

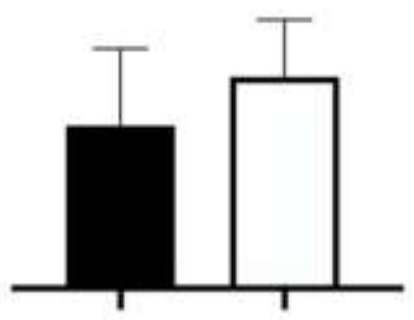

Hyperfunction Hypofunction MMP8
(B)

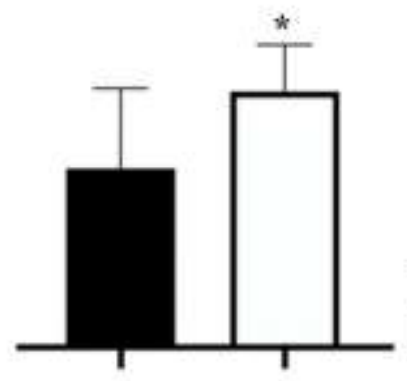

Hyperfunction Hypofunction MMP13
(C)

Hyperfunction Hypofunction

Source: Search data.

Table 1 shows the comparison between occlusal hypofunction and hyperfunction conditions. 
Table 1. Gene expression of MMP1, MMP8 and MMP13 in the odontogenic region of the lower incisors of both groups, in teeth with occlusal hypofunction and hyperfunction.

\begin{tabular}{|c|c|c|c|c|}
\hline Groups & Hypoestrogenism & $p$-value & Control & p-value \\
\hline \multicolumn{5}{|l|}{ Mean (SD) - MMP1 } \\
\hline Hypofunction tooth & $1.01(0.47)$ & \multirow{2}{*}{0.21} & $0.98(0.33)$ & \multirow{2}{*}{0.19} \\
\hline Hyperfunction tooth & $1.16(0.19)$ & & $0.65(0.02)$ & \\
\hline \multicolumn{5}{|l|}{ Mean (SD) - MMP8 } \\
\hline Hypofunction tooth & $0.98(0.43)$ & \multirow{2}{*}{0.16} & $0.99(0.39)$ & \multirow{2}{*}{0.33} \\
\hline Hyperfunction tooth & $0.58(0.23)$ & & $1.06(0.09)$ & \\
\hline \multicolumn{5}{|l|}{ Mean (SD) - MMP13 } \\
\hline Hypofunction tooth & $1.32(0.29)$ & \multirow{2}{*}{$0.045^{*}$} & $1.18(0.16)$ & \multirow{2}{*}{0.48} \\
\hline Hyperfunction tooth & $0.80(0.28)$ & & $0.93(0.51)$ & \\
\hline
\end{tabular}

Source: Authors.

\section{Discussion}

Some physiological and/or pathological conditions in the human body affects the odontogenic region causing alterations in the development of dental tissues (Omar et al., 2018). In this study, we established as an initial hypothesis that hypoestrogenism affects the expression of MMP1, MMP8 and MMP13 in the odontogenic region. To test this hypothesis, we used teeth with continuous growth in a murine model- rats. In this study, we also evaluated if the occlusal condition affected the MMPs expression. Therefore, the null hypothesis was rejected.

Estrogen receptors signaling pathways were associated with overexpression of MMPs (Jung et al., 2010; Lu et al., 2006), estrogen acts through its receptor and allowing the regulation of many genes. MMP1 has already been described as inversely related to the expression of sex steroid receptors in epithelial cells (Philips \& Devaney, 2003). Both receptors, ER $\alpha$ and ER $\beta$, were observed in cells in the odontogenic region. ER $\alpha$ expression was not affected under estrogen deficiency condition, while ER $\beta$ expression was increased in the odontogenic region in the hypoestrogenism group (Madalena, 2020). ER $\alpha$ can significantly increase the activity of the MMP13 promoter in particular, through the AP-1 activation site (Lu et al., 2006). ER $\beta$ signaling is more characterized by its performance in the nuclear signaling pathway, that is, the genomic signaling pathway (Hamilton et al., 2017). MMP8 (Orajarvi et al., 2011) and MMP13 were also differentially expressed in the mandibular condyle and tibia, respectively, of ovariectomized rats. However, in our present study, a statistical difference was not observed between hypoestrogenism and control groups, suggesting that the absence of estrogen is not an important factor in MMP1, MMP8, and MMP13 expression in the odontogenic region.

It is also important to report that the odontogenic region consisting basically of connective tissue and mineralized tissue. The increased expression of MMPs, especially the collagenases MMP1, MMP8, and MMP13, could influence collagen destruction in the periodontal ligament, affecting the occlusion. The first stages of remodeling of the periodontal ligament are marked by the action of collagenase, including MMP1, MMP8, MMP13, and MMP18, therefore, complete collagen degradation occurs through the action of MMPs gelatinase, MMP2, and MMP9 (Hui et al., 2001; Omar et al., 2018).

Initially, it was hypothesized that the mechanical force exerted in the hyperfunction tooth could increase the collagenases expression in the odontogenic region since, the express increase of some MMPs also seen in cells of the human periodontal ligament subjected to occlusal stress (Howard et al., 1988; Huang et al., 2008). The same hypothesis was applied in the hypoestrogenism group since an estrogen deficiency promotes fragility of the periodontal ligament (Wang \& McCauley, 2016). However, our results demonstrated that MMP13 was overexpressed in the occlusal hypofunction, mainly in the hypoestrogenism group. 
This interesting pattern was also observed in the experiment from Orajarvi et al. (2011) in which MMP8 positive cells was higher in the condylar cartilage of ovariectomized rats fed the soft diet than in non-ovariectomized control rats fed the soft diet. Also in their experiment, control rats fed with the normal diet had a higher MMP8 positive cells than control rats fed with the soft diet. Although the statistical difference was not observed for MMP8 in our study, it is possible this difference could be observed in an experiment with a larger sample.

In the study performed by Omar et al. (2018) also using rats' incisors as a model, they observed that the loss of occlusal contact, in rats submitted to hypofunctional eruption, increased MMP2 activity and eruption rate, but decreased MT1-MMP and TIMP-2 expression and disrupted collagen organization in the periodontal ligament. They concluded that occlusal contact may be an important factor for regulating the remodeling of the periodontal ligament against the continuous eruption process observed in rat incisors.

In our study, a statistical significant difference was observed only for MMP13 expression. MMP13 is highly important in collagen remodeling (Birkedal-Hansen et al., 1993; Souza \& Line, 2002). Under occlusal hypofunction condition there is a constant bone resorption related to the periodontal ligament, which is three times faster than in teeth with hyperfunctional condition (Gerlach et al., 2002). In addition to estrogen deficiency, which also demonstrates a significant change in collagen, modifying bone porosity, as well as disorganization of the collagen fibers of the periodontal ligament (Zhang et al., 2011). These facts could explain the results observed here.

Finally, our result pointed some interesting factors related to the molecular mechanisms involved in the occlusion and how systemic condition affect the expression of important molecules in odontogenic region. More studies are necessary to evaluate different pathways.

\section{Conclusion}

Occlusal function affects MMP13 expression in the odontogenic region, in murine model.

\section{Conflict of interest statement}

The authors declare that they have no conflict of interest.

\section{Acknowledgements}

We also thank to São Paulo Research Foundation - FAPESP (process \#2015/06866-5 and \#2016/08149-1) and the Coordenação de Aperfeiçoamento de Pessoal de Nível Superior - CAPES (CAPES - PROEX 0487).

\section{References}

Alhodhodi, A., Alkharobi, H., Humphries, M., Alkhafaji, H., El-Gendy, R., Feichtinger, G., Sperirs, V., \& Beattie, J. (2017). Oestrogen receptor $\beta$ (ER $\beta$ ) regulates osteogenic differentiation of human dental pulp cells. The Journal of steroid biochemistry and molecular biology, 174:296-302. 10.1016/j.jsbmb.2017.10.012.

Al-Majid, A., Alassiri, S., Rathnayake, N., Tervahartiala, T., Gieselmann, D. R., \& Sorsa, T. (2018). Matrix metalloproteinase-8 as an inflammatory and prevention biomarker in periodontal and peri-implant diseases. International journal of dentistry, 2018:7891323. 10.1155/2018/7891323.

Birkedal-Hansen, H., Moore, W. G. I., Bodden, M. K. L., Windsor, J., Birkedal-Hansen, B. C. A, \& Engler, J. A. (1993). Matrix metalloproteinases: A review. Critical reviews in oral biology and medicine: An official publication of the American Association of Oral Biologists, 4:197-250. $10.1177 / 10454411930040020401$.

Chen, G. X., Cai, C., Liu, J., Wen, L., Wang, X., \& Ding, Y. (2014). Impact of estrogen-related receptor $\alpha$ on the biological characteristics of rat mandibular condylar chondrocytes. Molecular medicine reports, 10(1):195-202. 10.3892/mmr.2014.2210.

Gerlach, R. F., Toledo, D. B., Fonseca, R. B., Novaes, P. D., Line, S. R. P., \& Merzel, J. (2002). Alveolar bone remodelling pattern of the rat incisor under different functional conditions as shown by minocycline administration. Archives of oral biology, 47(3):203-209. 10.1016/s0003-9969(01)00102-9. 
Hamilton, K. J., Hewitt, S. C., Arao, Y., \& Korach, K. S. (2017). Estrogen hormone biology. Current topics in developmental biology, 125:109-146. 10.1016/bs.ctdb.2016.12.005.

Hernandez, M., Valenzuela, M. A., Lopez-Otin, C., Alvarez, J., Lopez, J. M., Vernal, R., \& Gamonal, J. (2006). Matrix metalloproteinase-13 is highly expressed in destructive periodontal disease activity. Journal of periodontology, 77(11):1863-70. 10.1902/jop.2006.050461.

Howard, P. S., Kucich, U., Taliwal, R., \& Korostoff, J. M. (1998). Mechanical forces alter extracellular matrix synthesis by human periodontal ligament fibroblasts. Journal of periodontal research, 33:500-508. 10.1111/j.1600-0765.1998.tb02350.x.

Huang, S., Li, Y., Ren, Y., Cao, Z., \& Long, X. (2008). The effect of a single nucleotide polymorphism in the matrix metallop roteinase-1 (MMP-1) promoter on force-induced MMP-1 expression in human periodontal ligament cells. European journal of oral sciences, 116:319-323. 10.1111/j.1600-0722.2008.00552.x.

Hui, W., Rowan, A. D., \& Cawston, T. (2001). Insulin-like growth factor 1 blocks collagen release and down regulates matrix metalloproteinase-1, -3, -8, and 13 mRNA expression in bovine nasal cartilage stimulated with oncostatin-M in combination with interleukin 1alpha. Annals of the rheumatic diseases, $60: 254-$ 261. 10.1136/ard.60.3.254.

Jung, H. H., Park, Y. H., Jun, H. J., Kong, J., Kim, J. H., Kim, J. A.,Yun, J., Sun, J. M., Won, Y. W., Lee, S., Kim, S. T., Ahn, J. S., \& Im, Y. H. (2010). Matrix metalloproteinase-1 expression can be upregulated through mitogen-activated protein kinase pathway under the influence of human epidermal growth factor receptor 2 synergized with estrogen receptor. Molecular cancer research: MCR, 8(7):1037-47. 10.1158/1541-7786.MCR-09-0469.

Kanoza, R. J. J., Kelleher, L., Sodek, J., \& Melcher, A. H. (1980). A biochemical analysis of the effect of hypofunction on collagen metabolism in the rat molar periodontal ligament. Archives of oral biology, 25(10):663-668. 10.1016/0003-9969(80)90098-9.

Kilkenny, C., Browne, W. J., Cuthill, I. C., Emerson, M., \& Altman, D. G. (2010). Improving bioscience research reporting: The ARRIVE guidelines for reporting animal research. PLoS Biology, 8(6):e1000412. 10.1371/journal.pbio.1000412.

Kokorine, I., Marbaix, E., Henriet, P., Okada, Y., Donnez, J., Eeckhout, Y., \& Courtoy, P. J. (1996). Focal cellular origin and regulation of interstitial collagenase (matrix metalloproteinase-1) are related to menstrual breakdown in the human endometrium. Journal of cell science, 109:2151-2160.

Lee, C. K., Law, K. T., King, N. M., \& Rabie, A. B. M. (2002). A comparison between a conventional optical method and image-analysis for measuring the unimpeded eruption rate of the rat mandibular incisor. Archives of Oral Biology, 47(7):555-62. 10.1016/s0003-9969(02)00039-0.

Lee, Y. J., Lee, E. B., Kwon, E. E. Y., Lee, J. J., Cho, W. S., Kim, H. A., \& Song, Y. W. (2003). Effect of estrogen on the expression of matrix metalloproteinase (MMP)-1, MMP-3, and MMP-13 and tissue inhibitor of metalloproternase-1 in osteoarthritis chondrocytes. Rheumatology international, 23(6):282-8. $10.1007 / \mathrm{s} 00296-003-0312-5$.

Lu, T., Achari, Y., Sciore, P., \& Hart, D. A. (2006). Estrogen receptor alpha regulates matrix metalloproteinase-13 promoter activity primarily through the AP1 transcriptional regulatory site. Biochimica et biophysica acta, 1762(8):719-31. 10.1016/j.bbadis.2006.06.007.

Madalena, I. R. (2020). Influence of estrogen deficiency on the rate of tooth eruption in a murine model. (Thesis - PhD in Science) School of Dentistry of Ribeirão Preto, University of São Paulo, Ribeirão Preto, São Paulo, Brazil.

Manokawinchoke, J., Ritprajak, P., \& Osathanon, T. (2016). Estradiol induces osteoprotegerin expression by human dental pulp cells. Odontology, 104(1):1018. 10.1007/s10266-014-0178-x.

Nilsson, U. W., Garvin, S., \& Dabrosin, C. (2007). MMP-2 and MMP-9 activity is regulated by estradiol and tamoxifen in cultured human breast cancer cells. Breast cancer research and treatment, 102(3):253-6. 10.1007/s10549-006-9335-4.

Ojeda, S. R., Wheaton, J. E., Jameson, H. E., McCann, S. M. (1976). The onset of puberty in the female rat: changes in plasma prolactin, gonadotropins, luteinizing hormone-releasing hormone (LHRH), and hypothalamic LHRH content. Endocrinology, 98(3): 630-8. 10.1210/endo-98-3-630.

Omar, N. F., Gomes, J. R., Neves, J. S., \& Novaes, P. D. (2018). Effects of loss of occlusal contact on the expression of matrix metalloproteinase-2, membrane type 1-MMP, tissue inhibitor of the MMP-2, eruption rate, organization and resistance of collagen fibers of the rat incisor periodontal ligament. Journal of periodontal research, 53(1):40-46. 10.1111/jre.12484.

Omori, M. A., Marañón-Vásquez, G. A., Romualdo, P. C., Neto, E. C. M., Stuani, M. B. S., Matsumoto, M. A. N., Nelson-Filho, P., Proff, P., León, J. E., Kirschneck, C., \& Küchler, E. C. (2020). Effect of ovariectomy on maxilla and mandible dimensions of female rats. Orthodontics \& craniofacial research, 23(3):342-350. 10.1111/ocr.12376.

Orajarvi, M., Hirvonen, O., Yu, S.B., Liu, X., Tiilikainen, P., Wang, M., Raustia, A., \& Pirttiniemi, P. (2011). Effect of estrogen and altered diet hardness on the expression of estrogen receptor alpha and matrix metalloproteinase-8 in rat condylar cartilage. Journal of orofacial pain, 25(3):261-8.

Patel, S., Homeaei, A., Raju, A. B., \& Meher, B. J. (2018). Estrogen: The necessary evil for human health, and ways to tame it. Biomedicine \& pharmacotherapy = Biomédecine \& pharmacothérapie, 102:403-411. 10.1016/j.biopha.2018.03.078.

Paterni, I., Granchi, C., \& John, A. (2014). Estrogen receptors alpha (ER $\alpha$ ) and beta (ER $\beta)$ : subtype-selective ligands and clinical potential. Steroids, 15:13-29. 10.1016/j.steroids.2014.06.012.

Philips, N., \& Devaney, J. (2003). Beneficial regulation of type I collagen and matrixmetalloproteinase-1 expression by estrogen, progesterone, and its combination in skin fibroblasts Journal of the American aging Association, 26:59-62. 10.1007/s11357-003-0006-7.

Pizzol-Júnior, J. P., Sasso-Cerri, E., \& Cerri, O. S. (2018). Matrix metalloproteinase-1 and acid phosphatase in the degradation of the lamina propria of eruptive pathway of rat molars. Cells, 7(11):206. 10.3390/cells7110206. 
Research, Society and Development, v. 10, n. 5, e47810515311, 2021

(CC BY 4.0) | ISSN 2525-3409 | DOI: http://dx.doi.org/10.33448/rsd-v10i5.15311

Schiltz, C., Marty, C., Vernejoul, M. C., \& Geoffroy, V. (2008). Inhibition of osteoblastic metalloproteinases in mice prevents bone loss induced by oestrogen deficiency. Journal of cellular biochemistry, 104(5):1803-1817. 10.1002/jcb.21747.

Souza, A.P., \& Line, S. R. P. (2002). The biology of matrix metalloproteinases. Revista da Faculdade de Odontologia de Bauru, 10(1):1-6.

Tsubota, M., Sasano, Y., Takahashi, I., Kagayama, M., \& Shimauchi, H. (2002). Expression of MMP-8 and MMP-13 mRNAs in rat periodontium during tooth eruption. Journal of dental research, 81(10):673-8. 10.1177/154405910208101004.

Wang, C. W. J., \& McCauley, L. K. (2016). Osteoporosis and periodontitis. Current osteoporosis reports, 14(6):284-291. 10.1007/s11914-016-0330-3.

Zhang, L., Li, X., \& Bi, L. J. (2011). Alterations of collagen-I, MMP-1 and TIMP-1 in the periodontal ligament of diabetic rats under mechanical stress. Journal of periodontal research, 46(4):448-455. 10.1111/j.1600-0765.2011.01359.x. 